\title{
Soil Alteration Index Three and Soil Organic Matter in Response to Cover Crop Species and Management Practices
}

\author{
Adewole T. Adetunji, Bongani Ncube, Andre H. Meyer, Reckson Mulidzi, and Francis B. Lewu
}

\begin{abstract}
Alteration index three (A13), which measures the balances between three enzymes, can serve as a reliable means of detecting soil quality change due to management practices. This study aimed to evaluate the short-term effect of four living cover crops and residues, two termination stages and two termination methods on soil organic matter (SOM) and $\mathrm{Al} 3$ in a pot experiment. Species tested as cover crops were, vetch, pea, oats, rye and control (no cover crop). Soil was sampled at kill and one year. This study indicates significant interaction $(\mathrm{P}<0.05)$ between sampling time, cover crop and termination stage on SOM. It also indicates significant interaction $(\mathrm{P}<0.05)$ between sampling time and cover crop on Al3. Therefore, these management factors are key for optimizing cover crop benefits and soil fertility. The results also confirm that SOM and $\mathrm{Al} 3$ are suitable indicators of soil quality change caused by management practices.
\end{abstract}

Keywords - Alteration index three, cover crop, soil enzyme, organic matter

\section{INTRODUCTION}

Maintenance and improvement of soil fertility is the key to enhancing agricultural productivity and environmental quality [1]. In recent years, organic farming methods that conserve both nutrients and soil have become very important, hence management approaches involving cover crop cultivation are becoming more popular [2]. Cover cropping is a sustainable management approach that improves soil organic matter and soil physical properties, provides energy for microbial growth and acts as a driving force for nutrient mineralization/immobilization processes [3, 4]. There is, therefore, need to continually explore and manage cover crops in order to maximize their benefits and improve agricultural productivity.

Biological indices are promising means to evaluate soil quality status due to agricultural practices [5]. Soil microorganisms release enzymes, which catalyze and increase several biochemical reactions [6] that bring about decomposition of organic residues, nutrient cycling, and release of inorganic nutrients for plant growth [7-9]. Soil enzymes have been shown to respond rapidly to environmental changes and discriminate between different soil management practices $[10$,

Adewole T. Adetunji, Ph.D Student, Department of Environmental and Occupational Studies, Cape Peninsula University of Technology. South Africa.

Bongani Ncube, Andre H. Meyer, Reckson Mulidzi, and Francis B. Lewu, Cape Peninsula University of Technology. South Africa.
11]. This has greatly facilitated the adoption of soil enzyme activity as soil biological quality indicator under different cropping systems. Although a number of studies have reported cover crop use and management for soil quality improvement $[9,12]$, research evaluating how specific cover crop species, termination stage and termination method affect organic matter and enzyme activities, are limited in South African soils.

Reference [13] developed Al3 from studies evaluating the impact of different management and treatment regimes on soil enzyme activities. They found that smaller values of Al3 were related to greater soil quality. $\mathrm{Al} 3$ which measures the balance between three soil enzymes has also been indicated to be useful for determining soil quality in temperate grasslands of Galicia, North West Spain [14], conventional and organic treated apple orchards of Western Cape, South Africa [15] and compost amended soils in France [5]. Thus, evaluation of cover crop management impact on Al3 will aid better decision in choosing suitable methods that best enhance soil organic matter and fertility in agricultural soils.

The objectives of this study were to determine the effect of living cover crops and residues, termination stage and termination method on soil organic matter and $\mathrm{Al} 3$ under greenhouse conditions.

\section{MATERIALS AND MethodS}

\section{A. Experimental description}

A greenhouse pot experiment was conducted from August 2016 to November 2017 at the Agricultural Research Council (ARC) Experiment Farm, Bien donne, Western Cape Province,

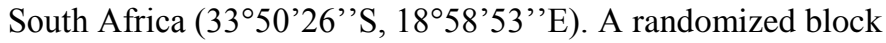
design was used and each treatment was replicated three times. Four experiments were set up which included two growth termination stages (vegetative and flowering) and two termination methods (slash and spray). Each experiment consisted of five cover crops namely; oats (Avena sativa L.), rye (Secale cereal L.), pea (Pisum sativum), vetch (Vicia dasycarpa Ten.) and a control (no cover crop). The soil was collected from $0-30 \mathrm{~cm}$ topsoil of the ARC Nietvoorbij Research Farm (3355'10'S, 18 51'58'E), Western Cape. The soil had sandy clay loam texture, with $61 \%$ sand, $14 \%$ silt and $25 \%$ clay, a $\mathrm{pH}(\mathrm{KCl})$ of $6.7,0.9 \% \mathrm{C}, 1.6 \% \mathrm{SOM}, 11 \mathrm{mg}$ kg-1 P (Bray II), $47 \mathrm{mg} \mathrm{kg-1} \mathrm{K,} 5.31 \mathrm{mg}$ kg-1 NO3-N and 10.36 mg kg-1 NH4-N. One hundred and twenty-30 cm plastic pots were evenly filled with $10.5 \mathrm{~kg}$ of the soil (air - dry weight) and 
arranged on benches. The average minimum and maximum temperature in the greenhouse was $0.5^{\circ} \mathrm{C}$ and $34^{\circ} \mathrm{C}$, respectively, and the plants were grown under natural light conditions.

Cover crops were seeded on August 5, 2016 at the following rates: oats, $160 \mathrm{~kg}$ ha- -1 ; pea, $100 \mathrm{~kg}$ ha -1 ; rye, $160 \mathrm{~kg}$ ha -1 ; vetch, $90 \mathrm{~kg}$ ha- -1 . Fertilizer was applied at $20 \mathrm{~kg} \mathrm{~N} \mathrm{ha}-1,150$ $\mathrm{kg} \mathrm{K}$ ha-1, and $50 \mathrm{~kg} \mathrm{P}$ ha-1 at planting. Additional $20 \mathrm{~kg} \mathrm{~N}$ ha -1 was applied to oats and vetch pots at $2-4$ leaf stage. Neither cover crop nor fertilizer was present in the control pots. Vetch and pea were inoculated with Rhizobium leguminosarium biovar viciae, before planting. Each pot was irrigated to field capacity using a drip irrigation system at planting. Irrigation was repeated after each soil had lost weight equivalent to a decrease in soil water content from field capacity to $25 \%$ soil water depletion [16]. Weeds were not controlled. Cover crops were terminated at vegetative (September 21 and 28, 2016) and flowering (October 26 and November 2, 2016) growth stages by clipping at the soil surface and spraying glyphosate (N-phosphonomethyl glycine) at the rate of $5 \mathrm{~L} \mathrm{ha-1}$. The cover crop residues were left on the soil surface to decompose.

\section{B. Soil sampling and analysis}

Soil samples were collected from the $0-15 \mathrm{~cm}$ depths of the trial pots just before cover crop kill and at one year after (September 21 and November 2, 2017). Soil samples were passed through $2 \mathrm{~mm}$ mesh. The SOM content of these samples was determined by combustion analysis [17]. The activities of $\beta$-glucosidase, phosphatase and urease known to play a critical role in carbon, phosphorus and nitrogen cycle, respectively, were determined from each sample using colorimetric methods [18-20]. The activities of $\beta$-glucosidase and phosphatase were expressed as $\mu \mathrm{g}$ p-nitrophenol g-1 soil h-1 while urease activity was expressed as $\mu \mathrm{g}$ ammonium g-1 soil $2 \mathrm{~h}-1$.

Alteration index three equation

The Al3 values were calculated with the following equation: $\mathrm{Al} 3=7.87 \beta$-glucosidase -8.22 phosphatase -0.49 urease .

\section{Statistical analysis}

Levene's test for homogeneity of experimental variances was verified for comparable variances [21]. The data were then subjected to a combined analysis of variance (ANOVA) using General Linear Models Procedure (PROC GLM) of Statistical Analysis Software (SAS) (Version 9.4; SAS Institute Inc, Cary, USA). Observations over sampling time (kill and one year) were combined in a split-plot analysis of variance with sampling time as a sub-plot factor [22] for soil variables. The Shapiro-Wilk test was performed on the standardized residuals from the model to verify normality [23]. Fisher's least significant difference was calculated at the 5\% level to compare treatment means [24]. A probability level of 5\% was considered significant for all significance tests.

\section{RESULTS AND DISCUSSION}

\section{A. Combined statistical analysis}

We observed from ANOVA significant interaction effects of sampling time, cover crop and termination stage treatments on SOM ( $\mathrm{P}=0.0361)$ (Table $\mathrm{I})$. There were significant sampling time and cover crop interaction effects on $\mathrm{Al3}(\mathrm{P}=0.0007)$ (Table I).

TABLE I: ANALYSIS OF VARIANCE (PR > F) FOR SOIL ORGANIC MATTER (SOM) AND SOIL ALTERATION INDEX THREE (AL3) DATA IN COMBINED SAMPLING TIMES AS AFFECTED BY COVER CROP SPECIES, TERMINATION STAGE, AND

\begin{tabular}{llll}
\multicolumn{4}{c}{ TERMINATION METHOD } \\
\hline Source & DF & SOM (\%) & Soil Al3 \\
\hline Method (M) & 1 & $<.0001$ & 0,0415 \\
Stage (S) & 1 & $<.0001$ & $<.0001$ \\
M x S & 1 & 0.0080 & 0,5348 \\
Block (Method*Stage) & 8 & 0.5320 & 0,1545 \\
Cover crop (CC) & 4 & 0.1363 & $<.0001$ \\
CC x M & 4 & 0.0002 & 0,2394 \\
CC x S & 4 & 0.0269 & 0,0313 \\
CC x M x S & 4 & 0.6767 & 0,2152 \\
Block (Method*Stage*Cover Crop) & 32 & & \\
Sampling Time (ST) & 1 & 0.1417 & $<.0001$ \\
ST x M & 1 & $<.0001$ & 0,6236 \\
ST x S & 1 & $<.0001$ & $<.0001$ \\
ST x M x S & 1 & $<.0001$ & 0,0152 \\
ST x CC & 4 & 0.2280 & 0,0007 \\
ST x CC x M & 4 & 0.0597 & 0,3466 \\
ST x CC x S & 4 & 0.0361 & 0,0516 \\
ST x CC x M x S & 4 & 0.0580 & 0,2619 \\
Error & 40 & - & - \\
Corrected Total & 119 & - & - \\
\hline The findings from this stidy & Sug & \\
\hline
\end{tabular}

The findings from this study suggest that cover crop species, termination stage and termination method are important management methods since they influenced SOM and Al3 in the short-term. The significant interaction effects of sampling time and cover crop on $\mathrm{Al} 3$ supports previous reports indicating that this index is sensitive to alterations in soil characteristics due to management practices $[15,25]$. Cover crops considerably add SOM and improve microbial activities thereby playing a vital role in soil ecosystem sustainability [26]. Several studies have shown that soil enzyme activity is a reliable biological indicator of alterations of soils in both natural and ecosystems $[10,27]$.

\section{B. Effect of cover crop species and sampling time on SOM and $\mathrm{Al3}$}

Living cover crops and residues had no significant effect on SOM at kill and one year, respectively (Table II). However, SOM in rye and oats residues were slightly higher than pea, vetch and the control.

At kill, Al3 values were significantly lower in all living cover crop treatments than the control $(-5.10)$ with rye $(-10.68)$ and oats (-9.69) being the lowest followed by pea (-7.66) and vetch (-7.62) (Table2). However, Al3 values were the same across all cover crop residues with the control treatments, at one year (Table II). 
TABLE II: COVER CROP SPECIES AND SAMPLING TIME EFFECTS ON SOIL ORGANIC MATTER (SOM) AND SOIL ALTERATION INDEX THREE (AL3) AT DIFFERENT SAMPLING TIMES (KILL AND ONE YEAR)

\begin{tabular}{llll}
\hline Sampling time & $\begin{array}{l}\text { Cover } \\
\text { crop }\end{array}$ & SOM $(\%)$ & Al3 \\
\hline Kill & Oats & $1,29( \pm 0.09) \mathrm{bc}$ & $-9,69( \pm 0.87) \mathrm{d}$ \\
& Pea & $1,26( \pm 0.08) \mathrm{c}$ & $-7,66( \pm 1.39) \mathrm{c}$ \\
& Rye & $1,30( \pm 0.08) \mathrm{abc}$ & $-10,68( \pm 0.93) \mathrm{d}$ \\
& Vetch & $1,36( \pm 0.08) \mathrm{abc}$ & $-7,62( \pm 1.48) \mathrm{c}$ \\
One year & Control & $1,34( \pm 0.10) \mathrm{abc}$ & $-5,10( \pm 1.31) \mathrm{b}$ \\
& Oats & $1,38( \pm 0.09) \mathrm{ab}$ & $-2,94( \pm 0.57) \mathrm{a}$ \\
& Pea & $1,31( \pm 0.09) \mathrm{abc}$ & $-2,88( \pm 0.53) \mathrm{a}$ \\
& Rye & $1,40( \pm 0.08) \mathrm{a}$ & $-2,33( \pm 0.36) \mathrm{a}$ \\
& Vetch & $1,34( \pm 0.08) \mathrm{abc}$ & $-2,42( \pm 0.29) \mathrm{a}$ \\
LSD & Control & $1,30( \pm 0.07) \mathrm{abc}$ & $-1,64( \pm 0.40) \mathrm{a}$ \\
\hline
\end{tabular}

Each value represents the mean $(\mathrm{n}=3)$ and standard error values are indicated in parenthesis. Different letters within a column indicate significant differences at $\mathrm{P}<0.05$ according to Fisher's least significant difference test (LSD)

There are limited information on the effect of living cover crops on SOM and soil microbial processes [28]. Most reports have been on cover crop residues and other management effects on soil ecosystem and fertility. This study indicates that living cover crops and residues did not have significant effect on $\mathrm{SOM}$, in the short-term. The initial high $\mathrm{C}$ content of the experimental soil might have contributed to SOM being undetectable in the short-term [29]. However, living cover crops have been indicated to improve SOM through root exudates and turnover [30]. The observed slightly higher SOM under rye and oats residues compared to control and other cover crops at one year is consistent with previous studies [1, 12]. Non-legumes/grasses have been widely reported to improve SOM than legumes due to higher $\mathrm{C}$ input $[12,31]$.

The observed lower Al3 values under all the living cover crops compared to the control is an indication that this biological index is sensitive to $\mathrm{C}$ inputs and soil alterations. Previous studies have shown that lower $\mathrm{Al} 3$ values indicate greater soil quality $[13,15]$. The much lower Al3 values detected under living oats and rye compared to pea and vetch is an indication that grasses increase labile $\mathrm{C}$ pools that serve as energy source for the soil biota in the rhizosphere [12, 32]. This study addressed to an extent the knowledge gap on the effect of living cover crop on Al3. However, at one year, Al3 was generally high and no response to cover crop residues were observed. This may be due to fluctuations in soil moisture and temperature pattern and substrate reduction, which occurs over time. The significant interaction effects of sampling time and cover crop on $\mathrm{Al} 3$ in the short-term suggests that this index may be more suitable/sensitive for detecting soil alterations from carbon inputs than SOM.

\section{Effect of cover crop species and termination stage on SOM and Al3 at different sampling times}

At kill, SOM was significantly greater at vegetative stage than flowering under all the living cover crops, whereas the control treatments of both termination methods were the same (Table III). At one year, SOM significantly increased and were greater at flowering stage compared to vegetative stage across all the cover crop residues with rye $(1.67 \%)$ and oats $(1.65 \%)$ being marginally higher than pea $(1.55 \%)$, vetch $(1.58 \%)$ and the control $(1.53 \%)$ (Table III). When averaged over all covers,
SOM was higher at vegetative stage than flowering, at kill and it was the other way round, at one year (Table IV).

At kill, Al3 values were significantly lower at vegetative stage than flowering across all living cover crops (Table III). Similarly, Al3 values were marginally lower at vegetative stage than flowering under oats, pea and vetch residues as well as the control, at one year (Table III). When averaged over all cover crops, vegetative stage had lower Al3 values compared to the flowering stage at both sampling times (Table IV).

TABLE III: COVER CROP SPECIES AND TERMINATION STAGE EFFECTS ON SOIL ORGANIC MATTER (SOM) AND SOIL ALTERATION INDEX THREE (AL3) AT

\begin{tabular}{|c|c|c|c|c|}
\hline \multicolumn{5}{|c|}{ DIFFERENT SAMPLING TIMES (KILL AND ONE YEAR) } \\
\hline $\begin{array}{l}\text { Sampling } \\
\text { time }\end{array}$ & $\begin{array}{l}\text { Cover } \\
\text { crop }\end{array}$ & $\begin{array}{l}\text { Termination } \\
\text { stage }\end{array}$ & SOM (\%) & Soil Al3 \\
\hline \multirow[t]{9}{*}{ Kill } & Oats & Vegetative & $\begin{array}{l}1,47( \pm 0.14) \\
\text { cdef }\end{array}$ & $-12,01( \pm 0,65) \mathrm{g}$ \\
\hline & Pea & & $1,44( \pm 0.10)$ def & $\begin{array}{l}-11,73( \pm 0,94) \\
\text { fg }\end{array}$ \\
\hline & Rye & & $\begin{array}{l}1,50( \pm 0.09) \\
\text { bcde }\end{array}$ & $-11,84( \pm 0,57) \mathrm{g}$ \\
\hline & Vetch & & $1,60( \pm 0.03) \mathrm{abc}$ & $\begin{array}{l}-11,36( \pm 1,85) \\
\text { fg }\end{array}$ \\
\hline & Control & & $1,37( \pm 0.12)$ ef & $-8,99( \pm 0,60) \mathrm{e}$ \\
\hline & $\begin{array}{l}\text { Oats } \\
\text { Pea }\end{array}$ & Flowering & $\begin{array}{l}1,11( \pm 0.05) \mathrm{g} \\
1,07( \pm 0.05) \mathrm{g}\end{array}$ & $\begin{array}{l}-7,37( \pm 0,88) \mathrm{e} \\
-3,59( \pm 1,00) \\
\text { bcd }\end{array}$ \\
\hline & Rye & & $1,10( \pm 0.02) \mathrm{g}$ & $-9,53( \pm 1,72)$ ef \\
\hline & Vetch & & $1,12( \pm 0.03) \mathrm{g}$ & $-3,88( \pm 0,78) \mathrm{cd}$ \\
\hline & Control & & $1,31( \pm 0.18) \mathrm{f}$ & $-1,21( \pm 1.08)$ a \\
\hline \multirow{9}{*}{ One year } & Oats & Vegetative & $1,10( \pm 0.05) \mathrm{g}$ & $-4,27( \pm 0.69) \mathrm{d}$ \\
\hline & Pea & & $1,06( \pm 0.05) \mathrm{g}$ & $\begin{array}{l}-3,64( \pm 0.75) \\
\text { bcd }\end{array}$ \\
\hline & Rye & & $1,14( \pm 0.03) \mathrm{g}$ & $\begin{array}{l}-2,43( \pm 0.66) \\
\text { abcd }\end{array}$ \\
\hline & Vetch & & $1,09( \pm 0.04) \mathrm{g}$ & $\begin{array}{l}-2,99( \pm 0.27) \\
\text { abcd }\end{array}$ \\
\hline & Control & & $1,07( \pm 0.03) \mathrm{g}$ & $\begin{array}{l}-2,16( \pm 0.57) \\
\text { abcd }\end{array}$ \\
\hline & $\begin{array}{l}\text { Oats } \\
\text { Pea }\end{array}$ & Flowering & $\begin{array}{l}1,65( \pm 0.02) \text { ab } \\
1,55( \pm 0.08) \\
\text { abcd }\end{array}$ & $\begin{array}{l}-1,60( \pm 0.50) a b \\
-2,12( \pm 0.65) \\
\text { abcd }\end{array}$ \\
\hline & Rye & & $1,67( \pm 0.04) \mathrm{a}$ & $\begin{array}{l}-2,23( \pm 0.34) \\
\text { abcd }\end{array}$ \\
\hline & Vetch & & $\begin{array}{l}1,58( \pm 0.03) \\
\text { abcd }\end{array}$ & $\begin{array}{l}-1,84( \pm 0.41) \\
a b c\end{array}$ \\
\hline & Control & & $\begin{array}{l}1,53( \pm 0.05) \\
\text { abcd }\end{array}$ & $-1,12( \pm 0.52) \mathrm{a}$ \\
\hline LSD & & & 0.15 & 2.21 \\
\hline
\end{tabular}

Each value represents the mean $(n=3)$ and standard error values are indicated in parenthesis. Different letters within a column indicate significant differences at $\mathrm{P}<0.05$ according to Fisher's least significant difference test (LSD)

TABLE IV: THE OVERALL EFFECT OF TERMINATION STAGE (VEGETATIVE AND FLOWERING) ON SOIL ORGANIC MATTER (SOM) AND SOIL ALTERATION INDEX THREE (AL3) AT DIFFERENT SAMPLING TIMES (KILL AND ONE YEAR)

\begin{tabular}{llll} 
Sampling time & $\begin{array}{l}\text { Termination } \\
\text { stage }\end{array}$ & SOM $(\%)$ & Soil Al3 \\
\hline Kill & Vegetative & $1,47( \pm 0.04) \mathrm{b}$ & $-11,19( \pm 0.48) \mathrm{d}$ \\
$\mathrm{I}$ & Flowering & $1,14( \pm 0.04) \mathrm{c}$ & $-5,12( \pm 0.72) \mathrm{c}$ \\
One year & Vegetative & $1,09( \pm 0.02) \mathrm{c}$ & $-3,10( \pm 0.29) \mathrm{b}$ \\
& Flowering & $1,60( \pm 0.02) \mathrm{a}$ & $-1,78( \pm 0.22) \mathrm{a}$ \\
LSD & & 0.07 & 0.99
\end{tabular}

Standard error values are indicated in parenthesis. Different letters within a column indicate significant differences $(\mathrm{P}<0.05)$ among treatments using Fisher's least significant difference test (LSD)

Termination at vegetative stage improved SOM compared to flowering across in all living cover crop treatments. Studies 
reporting the impact of different cover crop termination stages on SOM is scanty. Notwithstanding, a study assessing the effect of four legume cover crop termination stage on soil organic carbon (SOC) indicated greater level at the flowering stage than vegetative [33]. However, the observed higher SOM at flowering stage compared to vegetative at one year is consistent with previous work, which stated that delayed termination of cover crop correlated with higher biomass, residue cover, SOM and SOC content [33,34]. This study, therefore, suggests that soil residue cover and SOM can be optimized by terminating cover crops at the flowering stage.

Although we could not find literature to support the effect of cover crop termination stage on $\mathrm{Al} 3$, the lower index detected at vegetative stage at kill and one year of this study may be due to higher residue quality associated with early. Early termination at vegetative stage is associated with lower $\mathrm{C}: \mathrm{N}$ ratio and promotes soil biological nitrogen fixation and nutrient release [35]. However, literature have shown that delay in termination may lead to the accrual of plant root exudates and greater microbial biomass, which favors enzyme activities [32]. Although SOM and $\mathrm{Al} 3$ discriminated between termination stages in this study, further long-term research is required to know whether or not these observations transcend.

\section{Effect of termination method on SOM and Al3}

SOM in slash treatments was $\sim 4 \%$ greater than spray, when averaged over all cover crop residues (Table V). At one year, $\mathrm{Al} 3$ value was significantly lower in spray $(-2.74)$ treatments than slash (-2.14) when averaged over all cover crop residues (Table V).

TABLE V: THE OVERALL EFFECT OF TERMINATION METHOD (SLASH AND SPRAY) ON SOIL ORGANIC MATTER (SOM) AND SOIL ALTERATION INDEX THREE

\begin{tabular}{lll}
\multicolumn{2}{c}{$($ AL3) AT ONE YEAR } \\
\hline $\begin{array}{l}\text { Termination } \\
\text { method }\end{array}$ & SOM (\%) & Soil Al3 \\
\hline Slash & $1,37( \pm 0.05)$ a & $-2,14( \pm 0.25)$ a \\
Spray & $1,32( \pm 0.05) b$ & $-2,74( \pm 0.30) b$ \\
LSD & 0.05 & 0.60
\end{tabular}

Standard error values are indicated in parenthesis. Different letters within a column indicate significant differences $(\mathrm{P}<0.05)$ among treatments using Fisher's least significant difference test (LSD)

Findings from this study indicate that termination by slash favors SOM compared to spray at one year, which is in agreement with previous reports that application of glyphosate adversely affect C mineralization, SOC, SOM and soil microbial population in different cropping systems [36]. The major difference between both termination methods is that slash allows better surface residue cover and contact with the soil and maintains lower soil temperature and moisture which all contribute to higher SOC buildup, SOM and microbial activity [35].

The lower value of $\mathrm{Al} 3$ was however detected at termination by spray compared to slash probably indicating glyphosate effect. Some studies have reported the stimulating effect of glyphosate on soil biology [37, 38]. A study by Haney et al showed that glyphosate elevated microbial activity and $\mathrm{N}$ mineralization contrasting soils. Therefore, there is a need for further research on the effect of cover crop termination methods on $\mathrm{Al} 3$ and SOM under different soils in the short- and long-term.

\section{CONCLUSION}

To our knowledge, this is the first report of the impact of cover crop species, termination stage, combined with termination method on SOM and Al3 in South African cropping systems. Living cover crops and residues were slow to affect SOM. Rye and oats followed by pea are the most promising of the cover crop species with regard to $\mathrm{Al} 3$ and SOM increase. SOM varied with termination stages with vegetative being higher than flowering at kill and flowering being higher than vegetative at one year. Cover crop termination at vegetative stage favored Al3compared to flowering at both sampling times. Termination by slash enhanced SOM than spraying glyphosate, whereas $\mathrm{Al} 3$ indicated healthy soil under spraying. In general, there was significant interaction between sampling time, cover crop and termination stage, indicating that cover crop and growth termination stage have greater impact on SOM than termination methods. The significant interaction between sampling time and cover crop on $\mathrm{Al} 3$ is also a sign of cover crop relevance in soil fertility improvement. However, longer-term studies are needed to examine the consistency of these results.

\section{ACKNOWLEDGMENT}

We thank Barenbrug South Africa for supplying us with cover crop seeds. We also thank Isabella Van Huyssteen and Ncedo Ndololwana (Soil Science Department, ARC Infruitec/Nietvoorbij) for their technical support in the lab and field, respectively.

\section{REFERENCES}

[1] Fourie, J., G. Agenbag, and P. Louw, Cover crop management in a Chardonnay/99 Richter vineyard in the coastal region, South Africa. 3. Effect of different cover crops and cover crop management practices on organic matter and macro-nutrient content of a medium-textured soil. South African Journal for Enology and Viticulture, 2007. 28(1): p. 61. https://doi.org/10.21548/28-1-1461

[2] Muzangwa, L., C. Chiduza, and P. Muchaonyerwa, Feasibility of winter cover crop production under rainfed conditions in the eastern Cape Province of South Africa. African Crop Science Journal, 2013. 21(2): p. 173-184.

[3] Kaleeem Abbasi, M., M. Mahmood Tahir, N. Sabir, and M. Khurshid, Impact of the addition of different plant residues on nitrogen mineralization-immobilization turnover and carbon content of a soil incubated under laboratory conditions. Solid Earth, 2015. 6(1): p. 197-205. https://doi.org/10.5194/se-6-197-2015

[4] Murungu, F.S., C. Chiduza, P. Muchaonyerwa, and P.N. Mnkeni, Decomposition, Nitrogen, and Phosphorus Mineralization from Residues of Summer-Grown Cover Crops and Suitability for a Smallholder Farming System in South Africa. Communications in Soil Science and Plant Analysis, 2011. 42(20): p. 2461-2472. https://doi.org/10.1080/00103624.2011.609255

[5] Riah, W., N. Cheviron, J. Trap, S. Criquet, S. Houot, A. Bispo, C. Grand, G. Pérès, K. Laval, and I. Trinsoutrot-Gattin, "Effect or organic amendments on soil enzymatic activities. Results of the" Bioindicators" French program," in RAMIRAN 2013. 15th International Conference, Versailles, France, 3-5 June. 2013. Proceedings. 2013. Institut National de la Recherche Agronomique (INRA).

[6] Kujur, M. and A. Kumar Patel, Kinetics of soil enzyme activities under different ecosystems: An index of soil quality. Chilean journal of agricultural research, 2014. 74(1): p. 96-104.

https://doi.org/10.4067/S0718-58392014000100015 
[7] Baležentienè, L., Hydrolases Related to C and N. Cycles and Soil Fertility Amendment: Responses to Different Management Styles of Agro-Ecosystems. Polish Journal of Environmental Studies, 2012. 21(5): p. 1153-1159.

[8] Al-Kaisi, M., Myths and Facts about Residue Breakdown. 2014: Iowa State University.

[9] Du, Z., Y. Xie, L. Hu, L. Hu, S. Xu, D. Li, G. Wang, and J. Fu, Effects of Fertilization and Clipping on Carbon, Nitrogen Storage, and Soil Microbial Activity in a Natural Grassland in Southern China. 2014. https://doi.org/10.1371/journal.pone.0099385

[10] Adetunji, A.T., F.B. Lewu, R. Mulidzi, and B. Ncube, The biological activities of $\beta$-glucosidase, phosphatase and urease as soil quality indicators: a review. Journal of soil science and plant nutrition, 2017. 17(3): p. 794-807. https://doi.org/10.4067/S0718-95162017000300018

[11] Zhang, L., W. Chen, M. Burger, L. Yang, P. Gong, and Z. Wu, Changes in soil carbon and enzyme activity as a result of different long-term fertilization regimes in a greenhouse field. PloS one, 2015. 10(2): p. e0118371. https://doi.org/10.1371/journal.pone.0118371

[12] Mukumbareza, C., P. Muchaonyerwa, and C. Chiduza, Bicultures of oat (Avena sativa L.) and grazing vetch (Vicia dasycarpa L.) cover crops increase contents of carbon pools and activities of selected enzymes in a loam soil under warm temperate conditions. Soil Science and Plant Nutrition, 2016. 62(5-6): p. 447-455 https://doi.org/10.1080/00380768.2016.1206833

[13] Puglisi, E., A. Del Re, M. Rao, and L. Gianfreda, Development and validation of numerical indexes integrating enzyme activities of soils. Soil Biology and Biochemistry, 2006. 38(7): p. 1673-1681. https://doi.org/10.1016/j.soilbio.2005.11.021

[14] Paz-Ferreiro, J., C. Trasar-Cepeda, M. Leirós, S. Seoane, and F. Gil-Sotres, Biochemical properties in managed grassland soils in a temperate humid zone: modifications of soil quality as a consequence of intensive grassland use. Biology and Fertility of Soils, 2009. 45(7): p. 711-722. https://doi.org/10.1007/s00374-009-0382-y

[15] Meyer, A.H., J. Wooldridge, and J.F. Dames, Relationship between soil alteration index three (AI3), soil organic matter and tree performance in a 'Cripps Pink'/M7 apple orchard. South African Journal of Plant and Soil, 2014. 31(3): p. 173-175.

https://doi.org/10.1080/02571862.2014.944229

[16] Dohuky, M., C. Abdel, and N. Khalid, A Greenhouse Study on Growth, Yield and Anatomical Parameters of Three Pea Cultivars: under Different Irrigation Levels and Growth Regulators. American Journal of Experimental Agriculture, 2011. 1(4): p. 121. https://doi.org/10.9734/AJEA/2011/390

[17] Wooldridge, J., J. Fourie, and M.E. Joubert, Effects of soil surface management practices on soil and tree parameters in a 'Cripps Pink'/M7 apple orchard 1. Mineral nutrition. South African Journal of Plant and Soil, 2013. 30(3): p. 163-170. https://doi.org/10.1080/02571862.2013.854416

[18] Tabatabai, M. and J. Bremner, Use of p-nitrophenyl phosphate for assay of soil phosphatase activity. Soil Biology and Biochemistry, 1969. 1(4): p. 301-307. https://doi.org/10.1016/0038-0717(69)90012-1

[19] Eivazi, F. and M. Tabatabai, Glucosidases and galactosidases in soils. Soil Biology and Biochemistry, 1988. 20(5): p. 601-606. https://doi.org/10.1016/0038-0717(88)90141-1

[20] Kandeler, E. and H. Gerber, Short-term assay of soil urease activity using colorimetric determination of ammonium. Biology and Fertility of Soils, 1988. 6(1): p. 68-72. https://doi.org/10.1007/BF00257924

[21] Levene, H., Robust tests for equality of variances, p 278-292. Contributions to probability and statistics: essays in honor of Harold Hotelling. Stanford University Press, Palo Alto, CA, 1960.

[22] Little, T.M. and F. Hills, Statistical Methods in Agricultural Research UCD Book Store. 1972: Univ. Calif. Davis.

[23] Shapiro, S.S. and M.B. Wilk, An analysis of variance test for normality (complete samples). Biometrika, 1965: p. 591-611. https://doi.org/10.1093/biomet/52.3-4.591

[24] Ott, R.L. and M.T. Longnecker, An introduction to statistical methods and data analysis. 2015: Nelson Education.

[25] Paz-Ferreiro, J. and S. Fu, Biological indices for soil quality evaluation: perspectives and limitations. Land Degradation \& Development, 2016. 27(1): p. $14-25$ https://doi.org/10.1002/ldr.2262

[26] Dabney, S.M., J.A. Delgado, J.J. Meisinger, H.H. Schomberg, M.A. Liebig, T. Kaspar, J. Mitchell, and W. Reeves, Using cover crops and cropping systems for nitrogen management. Advances in nitrogen management for water quality, 2010: p. 231-282.

[27] Muzangwa, L., P.N.S. Mnkeni, and C. Chiduza, The Use of Residue Retention and Inclusion of Legumes to Improve Soil Biological Activity in Maize-Based No-Till Systems of the Eastern Cape Province, South Africa. Agricultural Research, 2019. https://doi.org/10.1007/s40003-019-00402-0

[28] Finney, D., J. Buyer, and J. Kaye, Living cover crops have immediate impacts on soil microbial community structure and function. Journal of Soil and Water Conservation, 2017. 72(4): p. 361-373. https://doi.org/10.2489/jswc.72.4.361

[29] Lagomarsino, A., M. Moscatelli, A. Di Tizio, R. Mancinelli, S. Grego, and S. Marinari, Soil biochemical indicators as a tool to assess the short-term impact of agricultural management on changes in organic $\mathrm{C}$ in a Mediterranean environment. Ecological Indicators, 2009. 9(3): p. 518-527.

https://doi.org/10.1016/j.ecolind.2008.07.003

[30] Dignac, M.-F., D. Derrien, P. Barré, S. Barot, L. Cécillon, C. Chenu, T. Chevallier, G.T. Freschet, P. Garnier, and B. Guenet, Increasing soil carbon storage: mechanisms, effects of agricultural practices and proxies. A review. Agronomy for sustainable development, 2017. 37(2): p. 14 https://doi.org/10.1007/s13593-017-0421-2

[31] Blanco-Canqui, H., T.M. Shaver, J.L. Lindquist, C.A. Shapiro, R.W. Elmore, C.A. Francis, and G.W. Hergert, Cover crops and ecosystem services: Insights from studies in temperate soils. Agronomy Journal, 2015. 107(6): p. 2449-2474. https://doi.org/10.2134/agronj15.0086

[32] Boyrahmadi, M. and F. Raiesi, Plant roots and species moderate the salinity effect on microbial respiration, biomass, and enzyme activities in a sandy clay soil. Biology and Fertility of Soils, 2018. 54(4): p. 509-521. https://doi.org/10.1007/s00374-018-1277-6

[33] Hirpa, T., Effect of stage at termination of legume green manures on soil organic carbon, yield and economic performance of subsequent maize crop. International Journal of Current Research and Academic Review, 2013. 1: p. 84-101.

[34] Ruis, S., H. Blanco-Canqui, P.J. Jasa, R. Ferguson, and G. Slater, Can cover crop use allow increased levels of corn residue removal for biofuel in irrigated and rainfed systems? BioEnergy Research, 2017. 10(4): p. 992-1004. https://doi.org/10.1007/s12155-017-9858-z

[35] Liang, S., J. Grossman, and W. Shi, Soil microbial responses to winter legume cover crop management during organic transition. European Journal of Soil Biology, 2014. 65: p. 15-22. https://doi.org/10.1016/j.ejsobi.2014.08.007

[36] García-Orenes, F., C. Guerrero, A. Roldán, J. Mataix-Solera, A. Cerdà, M. Campoy, R. Zornoza, G. Bárcenas, and F. Caravaca, Soil microbial biomass and activity under different agricultural management systems in a semiarid Mediterranean agroecosystem. Soil and Tillage Research, 2010. 109(2): p. 110-115. https://doi.org/10.1016/j.still.2010.05.005

[37] Weaver, M.A., L.J. Krutz, R.M. Zablotowicz, and K.N. Reddy, Effects of glyphosate on soil microbial communities and its mineralization in a Mississippi soil. Pest Management Science, 2007. 63(4): p. 388-393. https://doi.org/10.1002/ps.1351

[38] Lane, M., N. Lorenz, J. Saxena, C. Ramsier, and R.P. Dick, Microbial activity, community structure and potassium dynamics in rhizosphere soil of soybean plants treated with glyphosate. Pedobiologia, 2012. 55(3): p. 153-159. https://doi.org/10.1016/j.pedobi.2011.12.005

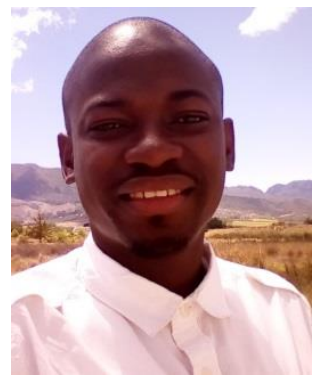

A.T. Adetunji completed his BTech in Agriculture (Crop production) at the Federal University of Technology (FUTA), Akure, Nigeria in 2010. He obtained his MTech in Agriculture (Crop management) at the Cape Peninsula University of Technology (CPUT), Cape Town, South Africa in 2015. Currently, he is a part-time lecturer and a doctoral fellow of Environmental Health at the Cape Peninsula University of Technology, with focus on soil quality management using cover crops and soil enzymes 